\title{
Correction to: Dragonfies of Dragon's Blood Island: Atlas of the Odonata of the Socotra Archipelago (Yemen)
}

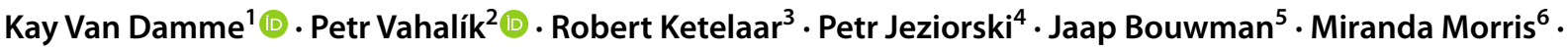 \\ Ahmed Saeed Suleiman ${ }^{7} \cdot$ Henri J. Dumont ${ }^{8}$ (i)
}

Published online: 14 June 2021

(c) The Author(s) 2021

\section{Correction to: \\ Rendiconti Lincei. Scienze Fisiche e Naturali (2020) 31:571-605 \\ https://doi.org/10.1007/s12210-020-00942-6}

The article Dragonfies of Dragon's Blood Island: Atlas of the Odonata of the Socotra Archipelago (Yemen), written by Kay Van Damme, Petr Vahalík, Robert Ketelaar, Petr Jeziorski, Jaap Bouwman, Miranda Morris, Ahmed Saeed Suleiman,Henri J. Dumont was originally published Online First without open access. After publication in volume, issue 31, page 571-605, the Authors requested that the article be Open Choice to make the article an open access publication on May 25th.

This article is licensed under a Creative Commons Attribution 4.0 International License, which permits use, sharing, adaptation, distribution and reproduction in any medium or format, as long as you give appropriate credit to the original author(s) and the source, provide a link to the Creative Commons license, and indicate if changes were made. The images or other third-party material in this article are included in the article's Creative Commons license, unless

The original article can be found online at https://doi.org/10.1007/ s12210-020-00942-6.

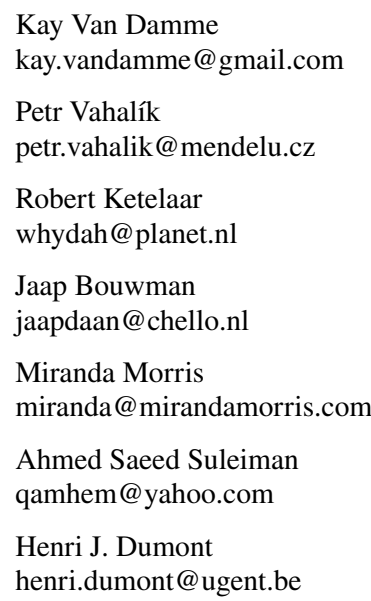

indicated otherwise in a credit line to the material. If material is not included in the article's Creative Commons license and your intended use is not permitted by statutory regulation or exceeds the permitted use, you will need to obtain permission directly from the copyright holder. To view a copy of this license, visit https://creativecommons.org/licen ses/by/4.0/.

The original article has been corrected.

Open Access This article is licensed under a Creative Commons Attribution 4.0 International License, which permits use, sharing, adaptation, distribution and reproduction in any medium or format, as long as you give appropriate credit to the original author(s) and the source, provide a link to the Creative Commons licence, and indicate if changes were made. The images or other third party material in this article are included in the article's Creative Commons licence, unless indicated otherwise in a credit line to the material. If material is not included in the article's Creative Commons licence and your intended use is not permitted by statutory regulation or exceeds the permitted use, you will need to obtain permission directly from the copyright holder. To view a copy of this licence, visit http://creativecommons.org/licenses/by/4.0/.

Publisher's Note Springer Nature remains neutral with regard to jurisdictional claims in published maps and institutional affiliations.

1 Senckenberg Research Institute and Natural History Museum Frankfurt, Senckenberganlage 25, 60325 Frankfurt am Main, Germany

2 Department of Forest Management and Applied Geoinformatics, Mendel University in Brno, Zemědělská 1, Brno 613 00, Czech Republic

3 Rhienderinklaan 25, 7231 DB Warnsveld, The Netherlands

4 Na Bělidle 1, Havírov-Suchá 735 64, Czech Republic

5 Huissensestraat 85, $6833 \mathrm{HM}$ Arnhem, The Netherlands

6 University of Saint Andrews, St Andrews, UK

7 Environmental Protection Agency, Socotra Branch, Hadiboh, Socotra Governorate, Yemen

8 Department of Biology, Ghent University, K.L, Ledeganckstraat 35, 9000 Ghent, Belgium 